\title{
PHILOSOPHY
}

\section{ГЕРМЕНЕВТИКА Х.-Г. ГАДАМЕРА ЯК ФІЛОСОФІЯ МОВИ}

\author{
Дубініна Віра Олександрівна, \\ Украӥнська медична стоматологічна академія, завідувачка кафедри філософії та суспільних \\ наук, кандидат філософських наук, доцент, Україна \\ ORCID ID: http://orcid.org/0000-0001-8024-9823
}

DOI: https://doi.org/10.31435/rsglobal_wos/31052020/7097

\section{ARTICLE INFO}

Received: 29 March 2020

Accepted: 10 May 2020

Published: 31 May 2020

\section{KEYWORDS}

hermeneutics, understanding, interpretation, application, language, meaning.

\begin{abstract}
The sequential development of H.-G. Gadamer philosophical doctrine of language as the basis of its philosophical hermeneutics. The various stages of representations of the language are analyzed in connection with the criticism of the instrumental approach and understanding of the language as the foundation of historical discourse and poetic creativity. The latter is considered as the pre-reflexive basis of the language, a fundamental expression of its essence. Moreover, artistic experience is presented as a procedure for knowing the truth, to the extent that this experience contains understanding, it itself is a hermeneutical phenomenon.

The linguistic turn, which marked one of the turning points in the development of modern philosophy, led to the formulation of a fundamentally new question about the essence of language. We are, of course, not talking about some kind of planned event or about any single process that coincides in its characteristics, or is something close to different philosophical directions. It is difficult to say how correctly it is to compare interest in language within the framework of linguistic philosophy and the phenomenological school, in the framework of which the development of hermeneutics took place.

The latter, from a method that was essentially intended to serve historical-philological and religious discourse, hermeneutics has evolved into an independent philosophical discipline that reflects the very essence of metaphysical issues. First of all, this change is connected with the development of the phenomenological tradition, and especially with the works of M. Heidegger, who was able to free hermeneutics from the excessive influence of theories of language and to base it on metaphysical inquiry. This, of course, does not mean that the language itself has been given to philosophical oblivion; it is only a matter of changing the accents and research attitudes.

This task, in our opinion, was set and largely solved by H.-G. Gadamer, in any case, if we accept his theoretical assumption about the transcendence of the meaning of the interpreter.

Gadamer interprets the hermeneutic phenomenon very broadly, in which he sees the integral unity of the three aspects - understanding, interpretation and application. Gadamer argues for their inseparability, an actual identity: understanding is always an interpretation and always implies an application of what is to be understood. The concept of application in Gadamer outlines the limits of the phenomenon to be interpreted and establishes the fact that all phenomena of spiritual culture in a particular situation must be understood differently.
\end{abstract}

Citation: Dubinina V. O. (2020) Hermeneutics H.-G. Gadamer as a Philosophy of Language. International Academy Journal Web of Scholar. 5(47). doi: 10.31435/rsglobal_wos/31052020/7097

Copyright: (C) 2020 Dubinina V.O. This is an open-access article distributed under the terms of the Creative Commons Attribution License (CC BY). The use, distribution or reproduction in other forums is permitted, provided the original author(s) or licensor are credited and that the original publication in this journal is cited, in accordance with accepted academic practice. No use, distribution or reproduction is permitted which does not comply with these terms. 
Лінгвістичний поворот, який ознаменував собою один 3 переломних моментів в розвитку сучасної філософії, привів до постановки принципово нового питання про сутність мови. Звісно, тут взагалі не йдеться про якусь сплановану подію або про якийсь єдиний процес, що збігається за своїми характеристиками, або є чимось близьким для різних філософських напрямків. Важко сказати, наскільки коректно порівнювати інтерес до мови, наприклад, в лінгвістичної філософії та феноменологічній школі, в рамках якої саме і відбувався розвиток герменевтики. Остання, 3 методу, що був покликаний, по суті, обслуговувати історикофілологічний і релігійний дискурс, перетворилася на самостійну філософську дисципліну, яка відображає саму суть метафізичної проблематики. В першу чергу така зміна зв'язується 3 розвитком феноменологічної традиції і особливо $з$ роботами М. Хайдеггера, який зумів звільнити герменевтику від надмірного впливу теорій мови $\mathrm{i}$ поставити іiі в основу метафізичного запитування. При цьому спостерігався і зворотний процес, коли розвиток філософської герменевтики стимулювався дослідженнями у царині філософії мови. Важливо зрозуміти, яким чином відбувається взаємозв'язок між інтерпретацією та розумінням і самою сутністю мови, що найбільш виразно представлена в поетичній творчості.

Таке завдання було поставлене і в значній мірі вирішене Х.-Г. Гадамером, у всякому разі, якщо прийняти його теоретичну установку про сутнісну автономність мови від мовного суб'єкту і про трансцендентність сенсу інтерпретатору.

У своїй статті ми розглянемо теорію мови Х.-Г. Гадамера у зв'язку з його проектом філософської герменевтики, спираючись перш за все на його фундаментальну працю «Істина i метод» [6; див. також 1]. Ми будемо також враховувати більш пізні роботи Гадамера [5], а також коментарі Ж. Грондена до головної праці Гадамера. [2].

Філософська герменевтика $€$ важливим етапом у розвитку європейської думки, невід'ємною частиною філософської рефлексії, що була підготовлена самою логікою розвитку філософії, мистецтва, літератури. Саме тому Гадамер приділяв так багато уваги аналізу і інтерпретації європейської культурної спадщини, античної філософії, поетичної творчості тощо.

Формування кола ідей, що склали основу філософської герменевтики Х.-Г. Гадамера, пов’язане з уявленнями про сутність мови і її ролі у формуванні сенсу і всієї духовної культури людства, а також від уявлень про людську індивідуальність, іiі створення та розвиток. Розгляд подібних питань $є$ принциповим для виявлення тієї дійсної ролі, яку герменевтичний проект зіграв і продовжує грати в розвитку європейської філософії.

Традиційним предметом герменевтики є розуміння - розсуд і освоєння смислових горизонтів, які представлені в текстових формах. Тексти можуть бути написані природними мовами, а також на умовних текстах інших мистецтв. В умовному сенсі текстом є будь-який слід цілеспрямованої людської діяльності - побут, архітектура, інші пластичні мистецтва і др. Саме герменевтика $з$ позиції Гадамера і $є$ спосіб читання та інтерпретації текстів, причому саме методологія роботи з текстами дозволяє створювати способи інтерпретації всіх інших культурних феноменів.

Перш за все, Гадамер піддає послідовної критиці будь-яке редукціоністське та інструментальні теорії мови. При цьому мова не йдеться про заперечення інструментальної ролі мови як такої. Гадамер вважає, що це лише найбільш помітна і часткова функція мови, свою ж основну роль мова виконує на дорефлексивному рівні. Мова представляється тут як своєрідний трансцендентальний медіум в якості антитези інструменталізму. Досить детально це питання розглядає А. Патлач у своїх роботах. [див. 3; 4].

Основою філософської герменевтики Гадамера стає твердження про те, що художній досвід - це досвід пізнання істини, так як він містить в собі розуміння, отже, і сам $\epsilon$ герменевтичним феноменом. Розуміння ж є фактом зустрічі з твором мистецтва, яке «може бути прояснене тільки виходячи зі способу буття твору мистецтва» [6, с. 146].

Людське ставлення до світу, згідно Гадамеру, універсально в тому сенсі, що між будьякими людьми в яких би то не було обставинах, існує можливість взаєморозуміння. Така установка питання пов'язана 3 тим, що мова, що утверджується в якості індивідуального інструменту, по суті $\epsilon$ суспільним явищем. Гадамер порівнює мову з суспільством, що на неї розмовляє, і пояснює, що мова $є$ засобом зв'язку між людьми, тим, що з'єднує їх існування. У строгому сенсі, не буває чисто приватної мови, так як з перших років життя ми входимо в мову, переймаючи ії від інших. Мова відкриває цей світ для нас в якості розкриття сущого, досвіду світу: «Не тільки світ є світом лише 
остільки, оскільки він отримує мовне вираження, - але справжнє буття мови в тому тільки й полягає, що в ньому виражається світ. Таким чином, вихідна людяність мови означає разом з тим споконвічно мовний характер людського буття-в-світі» [6, с. 513].

Це висвітлення соціальне за своєю природою, що можна угледіти ще при базовому визначенні мови: «... Мова знаходить своє справжнє буття лише в розмові, тобто при здійсненні взаєморозуміння. <..> Це життєвий процес, в якому проживається саме життя людського суспільства. <..> Людську мову слід мислити як особливий і єдиний у своєму роді процес остільки, оскільки в процесі мовного взаєморозуміння розкривається «світ». <...> Всі форми людської життєвої спільноти суть форми спільноти мовної, більше того: вони саме і утворюють мову» $[6$, с. 516$]$.

Якщо в «Істині i методі» Гадамер вибудовує концепцію універсального трансценденталізму, то, як вірно вказує А. Патлач, в більш пізніх роботах, присвячених мові,

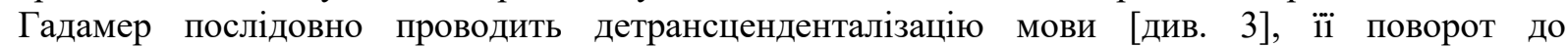
феноменальності, в якій мова реалізується безпосередньо. Мова йдеться не тільки про мову повсякденності, якої іманентно притаманне смислове наповнення. Гадамер розуміє, що основне завдання тієї форми дискурсу, яку він прагне створити - це аж ніяк не герменевтика буденності або повсякденної мови. Головне завдання філософської герменевтики двояка - це розгляд і інтерпретація історії та історичних наративів і розуміння поетичної творчості, яка виступає в якості квінтесенції історичного досвіду.

Одна 3 основних особливостей поетичного слова, за Гадамером, полягає в тому, що мова, здійснюючи саморепрезентацію, реалізує багатозначність, яка $є$ не стільки відмітною властивістю саме поетичної мови, скільки належить сутності самої мови, що розуміється не як зібрання слів, а як абсолютно універсальне слово, яка не тільки має певне значення, але завжди відсилає до цілого змісту. Ось чому слово в своїй тілесності відрізняється від інших матеріалів мистецтва. Гадамер вважає, що там, де звучить слово, викликається вся мова в цілому, а також все, що на неї може бути сказано. Але в тому і річ, що на мові може бути сказане все.

Це досить сміливий і доволі загальний тезіс, в якому неважко побачити старі уявлення Гадамера про трансцендентність мови і іï загальний характер. Це своєрідний лінгвістичний платонізм, з яким, звичайно ж, не погодяться численні скептики і номіналісти. Останнім важко дорікнути в злому намірі або в приховуванні істини, оскільки легко зрозуміти мотив, який ними рухає - потреба перетворити вільний і метафоричний дискурс про мову і їі можливості в справді науковий розгляд мови. Не будемо забувати, що сучасна наука являє собою не що інше, як систему організованого скептицизму, який прагне очистити наше пізнання від релятивізму, розмитих формулювань або посилань на інтуїцію. Сучасні психолінгвістичні, структуралістські або когнітивні дослідження мови також висловлюють їі сутність.

Яке ж місце філософської герменевтики в ряду подібних досліджень. Наскільки вона взагалі здатна виконати своє призначення? Для Гадамера тут немає проблеми або суперечності, оскільки жоден вид філософського дискурсу про мову не заперечує іншого, але всі вони в кінцевому рахунку виконують одну задачу -створення єдиного, цілісного ейдосу мови. В рамках цього завдання Гадамер відводить герменевтиці роль ейдеттчної, трансцендентальної, метафізичної теорії, яка покликана об'єднати всі розрізнені дискурси про мову в єдине ціле.

Гадамер вказує на особливість людської мови і ставлення до світу на відміну від абсолютно інструментальної поведінки і «мови» тварин: «Піднесення над навколишнім світом спочатку має тут людський, а це значить, мовний сенс. Тварина може покинути навколишній світ, може обійти всю землю, не розриваючи, однак, своєї пов'язаності навколишнім світом. Навпаки, піднесення над навколишнім світом є для людини піднесенням до світу; він не залишає навколишній світ, але стає до нього в іншу позицію, у вільне, дистанційоване ставлення, здійснення якого завжди є мовним. Мова звірів існує лише per acquivocationen (за уподібненням). Адже мова в її вживанні є вільна і варіативна можливість людини. Мова варіативна не тільки в тому сенсі, що є також і інші, іноземні мови, які ми можемо вивчити. Мова ще й сама по собі варіативна, оскільки надає людині різні можливості для висловлення одного й того ж» [6, с. 476].

3 цього можна зробити висновок про те, що принцип мімесіса в мові означає, що слово наслідує не тільки одиничної речі, але світу в цілому, тобто порядку, який, подібно до невидимої гармонії, не виражається, а присутня в слові. Така присутність порядку можлива там, де відсутня дистанція між здоровим глуздом і чуттєвим явищем, тобто в поетичному слові. 
Отже, говорячи про саморепрезентацію мови в поезії, Гадамер має на увазі, що в поетичному слові віднесення до зовнішнього світу виводиться за дужки, так як в ньому мова виступає не як інструмент осмислення світу, але як загальне «ось» (Da) буття. Одне з найбільш відомих визначень мови, по Гадамеру, це - «буття, яке може бути зрозуміле» [6, с. 548]. Буття і $\epsilon$ уявлення-себе-самого і воно якраз і є справжнє буття мови, отже, ми можемо говорити про те, що в поетичному слові виявляє себе буття як ціле.

У якості найбільш характерного виявлення сутності мови, Гадамер досліджує завдання історичної науки. На думку Гадамера, у історика, що звертається до будь-якого історичного тексту, завжди є деякий «попереднє розуміння» цього тексту, задане йому традицією, в якій він живе і мислить; воно може коригуватися в процесі роботи над текстом, але історик не може повністю звільнитися від передумов свого мислення: мислення без передумов не існує, оскільки буття - це час, а людський досвід маэ кінцевий характер. Для характеристики попереднього розуміння Гадамер використовує слово «забобон», яке, каже Гадамер, до епохи Просвітництва не мало звичного для нас значення. Забобон означає щось, що передує міркуванням і роздумам, деяку дорефлексивного установку свідомості. 3 точки зору філософії, забобон - невід'ємна характеристика свідомості, наскільки остання розуміється історично. Відмовитися від забобону повністю неможливо, але можна, як каже Гадамер, привести його у зважений стан - в цьому і полягає завдання історика. Умовою досягнення такого стану $є$ наявність часової дистанції між дослідником і тим, що досліджується.

Джерело герменевтики Гадамера: «...герменевтичний аспект не може обмежуватися герменевтичними науками - мистецтвом, історією, не може обмежуватися спілкуванням 3 текстами: універсальність герменевтичної проблеми, яку вже мав за мету Шлейермахер, відносяться до сукупності всього розумного» [6, с. 260]. Гадамер доволі вільно трактує сам герменевтичний феномен, в якому він вбачає інтегральну єдність трьох аспектів - розуміння, інтерпретації і аплікації.

Гадамер стверджує їх нероздільність, фактичну тотожність: розуміння завжди $\epsilon$ тлумачення і завжди передбачає аплікацію того, що підлягає розумінню. Поняття аплікації у Гадамера окреслює межі феномену, який підлягає інтерпретації, і встановлює той факт, що всі феномени духовної культури в тій чи іншій ситуації повинні розумітися по-іншому.

Мовний характер людського досвіду світу розширює горизонт нашого аналізу герменевтичного досвіду. Підтверджується те, що ми вже бачили на прикладі перекладу і тих можливостей взаєморозуміння, при яких ми виходимо за межі нашої власної мови, а саме: мовний світ, в якому ми живемо, не є межа, що перешкоджає пізнанню в-собі-буття, але цей світ в принципі охоплює собою все, у що може проникнути, до чого може піднятися наше пізнання.

У ключовий роботі Гадамера постійно виражається думка про самостійність i «вселенськість», абсолютність мови: «... в мові виражає себе (sich darstellt) сам світ. Мовний досвід світу «абсолютний». Він височить над відносністю всіх наших буттєвих позицій (Relativitzten von Seinssetzung), оскільки охоплює собою будь-яке по-собі-буття, в якому би зв'язку воно не поставало перед нами. Мовний характер нашого досвіду світу передує всьому, що ми пізнаємо і висловлюємо як суще. Основний зв'язок між мовою і світом не означає того, що світ стає предметом мови. Швидше за все, те, що $є$ предметом пізнання і висловлювання, завжди вже оточене світовим горизонтом мови. Мовний характер людського досвіду світу не включає в себе предметність світу» [6, с. 482].

Наскільки раціональні подібні судження? Чи не є це просто вільної метафорою, за якою ховається традиційне для західної філософії гіпостазування понять. У цьому не важко помітити вплив платонізму. В даному випадку Гадамер гіпостазує мову в цілому, тут на відміну від позиції Хайдеггера, мова - це не дім буття, але, скоріше, саме буття, або, як найменше, істина буття. В іншому місці філософ заявляє про те, що мова є мовою самого розуму. [див. 6, с. 467].

3 точки зору Гадамера в мовному оформленні людського досвіду світу відбувається не вимір або облік того, що є в наявності, але знаходить голос саме суще в тому вигляді, в якому воно в якості сущого і значущого виявляє себе людина. Саме в цьому - а не в методологічному ідеалі раціонального конструювання, який панує в сучасній науці, - впізнає себе здійснюване в науках про дух розуміння. Якщо раніше використовували для характеристики способу здійснення практичної історичної свідомості поняття його мовної природи, то причина цього в тому, що мовний характер має людський досвід світу взагалі. [6, с. 488]. 
Таким чином, ми виявляємо певну єдність в розумінні Х.-Г. Гадамером проблематики філософії мови і завдань філософської герменевтики. Ця єдність обумовлена сутнісними характеристиками мовного середовища, яке представляє собою один 3 найважливіших антропологічних чинників, неодмінну умову людського існування, ейдетичний фон, на якому розгортається наша суб'єктивність. Ця єдність також не $є$ однаковістю, скоріше мова йде про різницю аспектів розгляду мови і її можливостей, про прихований ізоморфізм герменевтичного дискурсу, лінгвістичної ейдетики і технічних, інструментальних процедур.

Звісно ж, що саме така точка зору дозволяе врахувати і охопити найбільш істотні характеристики і прояви мови: по-перше, це побудова дискурсу повсякденності у всьому його різномаїтті і варіативності; по-друге, забезпечення нашого пізнання, з усією його технічністю і впорядкованістю, точним і надійним мовним інструментарієм; нарешті, по-третє, пошук необхідної тональності в розумінні поетичної творчості, царині, в якій реалізує себе герменевтичний метод.

\section{ЛІТЕРАТУРА}

1. Гадамер Х.-Г. Истина и метод: Основы философской герменевтики. - М.: Прогресс, 1988. - 704 c.

2. Гронден Ж. К композиции «Истины и метода» // Религия. Церковь. Общество. Вып. V. - СПб.: РХГА, 2016. - С. 42-68.

3. Патлач А.И. Философия языка Х.-Г. Гадамера. - Дис. ... канд. филос. наук. Специальность 09.00.03 - история философии. - М.: МГУ, 2011. $-210 \mathrm{c}$.

4. Патлач А.И. Философия языка М. Хайдеггера и Х.-Г. Гадамера (историко-философский анализ). Философские науки. - 2011, № 7. - С. 104-114.

5. Gadamer H. G. Kleine Schriften, Bd. 4. Tübingen, 1977, S. 256-261.

6. Gadamer H.-G. Gesammelte Werke. Bd. 1. - Hermeneutik I. - Wahrheit und Methode. - Tübingen, 1990, $494 \mathrm{~s}$. 